\title{
Effects of Polyvinylpyrrolidone and Ethyl Cellulose in Polyurethane Electrospun Nanofibers on Morphology and Drug Release Characteristics
}

\section{Elektro-Eğirme Yöntemi ile Üretilen Poliüretan Nanoliflerin Morfolojileri ve İlaç Salım Özellikleri Üzerinde Polivinilpirolidon ve Etil Selülozun Etkileri}

\author{
(D) Aslı GENÇTÜRK1, (D) Emine KAHRAMAN22, (D) Sevgi GÜNGÖR22, (D) Yıldız ÖZSOY2*, (D) A. Sezai SARAÇ1,3 \\ 1istanbul Technical University Faculty of Science and Letters, Department of Polymer Science and Technology, İstanbul, Turkey \\ 2istanbul University Faculty of Pharmacy, Department of Pharmaceutical Technology, İstanbul, Turkey \\ 3istanbul Technical University University Faculty of Science and Letters, Department of Nanoscience and Nanoengineering, İstanbul, Turkey
}

\begin{abstract}
Objectives: Polyurethanes (PUs) are a popular choice for composing nanofibers due to their spinnability, biocompatibility, high chemical stability, and good mechanical and elasticity properties. The desired release behaviors are also achieved by using combinations of PUs and various polymers. In this study, we investigated effects of polyvinylpyrrolidone (PVP) and ethyl cellulose (EC) on PU electrospun nanofibers in terms of morphological structures and drug release characteristics.

Materials and Methods: Nanofibers were prepared using blends of PU with either EC or PVP in different ratios by electrospinning. The effects of PVP or EC on the morphology and diameter of the prepared nanofibers were examined with scanning electron microscope (SEM). The compatibility of the components used in the formulations of nanofibers was determined by attenuated total reflection (ATR)-fourier-transform infrared (FTIR). Donepezil hydrochloride (DNP), a water soluble compound, was selected as a model drug to examine its release characteristics from both PU/PVP and PU/EC electrospun nanofibers. In vitro drug release studies from electrospun nanofibers were performed according to the method defined in the monograph as the "paddle over disk method" of United States Pharmacopeia 38.

Results: The SEM images showed that addition of EC or PVP to PU solutions did not affect the generation of nanofibers, and those formed had a smooth surface without beads in nanoscale. The ATR-FTIR spectra disclosed that EC and PVP were separately incorporated into the PU matrix. The in vitro release data indicated that the presence of EC or PVP in PU nanofibers dramatically changed the release behavior of DNP. PU/EC nanofibers (F4) provided sustained drug release with the Korsmeyer-Peppas drug release kinetic mechanism, in which the release rate was controlled by diffusion of the drug, while all of the PU/PVP nanofibers exhibited fast drug release.

Conclusion: Overall, these characteristics of PU/EC (10/8) electrospun nanofibers has suggested their potential use as a drug carrier from which water-soluble drug release may occur in a sustained fashion.

Key words: Electrospun nanofibers, drug release, polyurethane, polyvinylpyrrolidone, ethyl cellulose

öz

Amaç: Poliüretanlar (PU) eğirmelerinin kolaylığı, biyouyumlulukları, yüksek kimyasal stabiliteleri ve iyi mekanik ve elastik özelliklere sahip olmaları nedeniyle nanoliflerin kompoze edilmeleri için sıklıkla tercih edilirler. PU'lar ve çeşitli polimerlerle bileşimleri kullanılarak istenen salım davranışları da elde edilmektedir. Bu çalışmada, elektro-eğirme yöntemi ile üretilen PU nanoliflerin morfolojileri ve ilaç salım özellikleri üzerinde polivinilpirolidon $(P V P)$ ve etil selülozun (EC) etkisini araştırdık.

Gereç ve Yöntemler: Nanolifler farklı karışımlardaki PU'nun farklı oranlarda EC veya PVP ile birlikte kullanılması ile elektro-eğirme yöntemiyle hazırlanmıştır. Hazırlanan nanoliflerin morfolojisi ve çapı üzerinde PVP veya EC'nin etkisi taramalı elektron mikroskobu (SEM) ile incelenmiştir. Nanolif formülasyonlarında kullanılan maddelerin geçimliliği zayıflatılmış toplam yansıma üniteli fourier dönüşümlü kızılötesi spektroskopisi (ATRFTIR) ile belirlenmiştir. Hem PU/PVP hem de PU/EC nanoliflerin salım davranışlarını incelemek için suda çözünen bir madde olan donepezil hidroklorür (DNP) model ilaç olarak seçilmiştir. Elektro-eğirme yöntemi ile hazırlanan nanoliflerden ilaç salım çalışmaları Amerikan Farmakopesi 38'de tanımlanan “disk üzerinde palet yöntemine" göre yapılmıştır.
\end{abstract}

*Correspondence: E-mail: yozsoy@istanbul.edu.tr, Phone: +90 21244000 00-13498 ORCID-ID: orcid.org/0000-0002-9110-3704

Received: 03.09.2019, Accepted: 31.10.2019

๑Turk J Pharm Sci, Published by Galenos Publishing House. 
Bulgular: SEM görüntüleri, EC'nin veya PVP'nin PU çözeltisine eklenmesinin nanolif oluşumunu etkilemediğini; oluşan nanoliflerin pürüzsüz yüzeye sahip olduğunu ve boncuk şeklinde yapılar içermediğini göstermiştir. ATR-FTIR spektrumları ise EC ve PVP'nin ayrı ayrı PU matrikse yüklendiğini ortaya koymaktadır. In vitro salım verileri, PU nanoliflerde EC veya PVP varlığının DNP'nin salım davranışını önemli ölçüde değiștirdiğini göstermiştir. PU/PVP nanolifleri sürekli ilaç salımı sergilemiș ve PU/EC nanolifleri (F4) ise salım hızının ilacın difüzyonuyla kontrol edildiği Korsmeyer-Peppas kinetik mekanizması ile uyumlu uzatılmış ilaç salımı sağlamıştır.

Sonuç: Sonuçta, elektro-eğilme yöntemiyle üretilen PU/EC (10/8) nanoliflerin sürekli şekilde suda çözünür ilaç salımı sağlayan özellikleri, bu yapıların ilaç taşıyıcısı olarak potansiyel kullanımları olabileceğini göstermektedir.

Anahtar kelimeler: Elekro-eğirme yöntemi ile üretilen nanolifler, ilaç salımı, poliüretan, polivinilpirolidon, etil selüloz

\section{INTRODUCTION}

Electrospun nanofibers have attracted great attention because of their potential applications for biomedical devices, tissue engineering, biosensors, filtration, wound dressing, and enzyme immobilization in recent years. 'They have also received considerable attention in drug delivery especially because of their high surface area to volume ratio, which might permit drug molecules to diffuse out of the matrix promptly due to the highly porous structure. ${ }^{2,3}$ Additionally, electrospun nanofibers have other superiorities such as high drug loading capacity, cost effectiveness, and ease of fabrication. ${ }^{4}$

Polyurethanes (PUs) are widely used for composing nanofibers due to their spinnability, biocompatibility, chemical stability, and good mechanical and elasticity properties. They could generally be adapted for many applications such as filters, wound dressing, biosensors, biomedical devices, and tissue engineering, owing to their various structures. ${ }^{5}$ The addition of a second component such as cellulose derivatives, polyethylene glycol, and polycaprolactone to PUs could give rise to the fabrication of a new type of nanofiber with different morphological and physical structures for special applications.,7 The desired release behaviors are also achieved using various polymer combinations. $^{8}$

Ethyl cellulose (EC) is a non-ionic and physiologically inert cellulose derivative. This material, which is insoluble in aqueous media, has a moderately low swelling degree. ${ }^{9}$ Thus, it is an appropriate compound for the production of a sustained drug release matrix ${ }^{10}$ and does not require addition of release modifiers. ${ }^{11}$

Polyvinylpyrrolidone (PVP) is a nonionic, biodegradable, and biocompatible polymer produced from monomer $\mathrm{N}$-vinylpyrrolidone. ${ }^{12,13}$ It has outstanding spinnability in various solvents such as ethanol, methanol, and chloroform. ${ }^{12,14}$ PVP has a hygroscopic property, so that it absorbs water up to $40 \%$ of its weight in atmospheric conditions and could result in unstable nanofibers. However, besides these properties, PVP is a hydrophilic polymer that leads to fast dissolution and immediate release of drugs. ${ }^{15}$ PVP has already been used to modulate the release of drugs from nanofibers. ${ }^{16}$ The drug release from PVP, EC, or PVP/EC nanofibers has been studied by various researchers. ${ }^{17-20}$ However, the morphology and drug release characteristics of electrospun fibers composed of blends of PU with either EC or PVP are not yet available in the literature.

In the present study, we proposed to investigate effect of EC and PVP in PU electrospun nanofibers on morphology and drug release characteristics. At the second stage, fibers were prepared from PU and either hydrophobic polymer EC or hydrophilic polymer PVP blends in different combinations. PU/EC and PU/PVP fibers were assessed as a carrier system to determine the drug release profile. The developed PU/ EC and PU/PVP nanofibers in different combinations were characterized morphologically and structurally. At the second stage, effects of EC or PVP on the release rates of donepezil hydrochloride (DNP), which is a water-soluble drug, were examined and their kinetic mechanisms were estimated based on in vitro release data.

\section{MATERIALS AND METHODS}

\section{Materials}

PU; Mw 93,000 g/mol was purchased from Flokser Corporation (Turkey). EC and PVP K30 were supplied by Dow (United States) and Hangzhou Sunflower Technology (China), respectively. $\mathrm{N}, \mathrm{N}$-dimethylformamide was obtained from Labkim (Turkey). DNP was given as a kind gift by Santa Farma Pharmaceutical Company (Turkey). All of the chemical materials were of analytical grade.

\section{Production of electrospun nanofibers}

Homogeneous PU solutions were prepared by dissolving PU $(12.5 \%, w / v)$ in dimethylformamide. DNP was added to these clear polymer solutions and it was dissolved. Following the addition of either EC or PVP at different ratios to PU solutions (Table 1), the mixtures were stirred for $1 \mathrm{~h}$ to provide a homogeneous solution for electrospinning.

The conductivity of solutions was determined by a conductivity meter (Eutech Instruments, Netherlands) at $25^{\circ} \mathrm{C}$. Each of the measurements was conducted at least three times.

In the electrospinning process (Figure 1), each of the mixed polymer solutions was loaded into a $10 \mathrm{~mL}$ syringe equipped

Table 1. Composition of nanofiber solutions

\begin{tabular}{llllll}
$\begin{array}{l}\text { Formulation } \\
\text { code }\end{array}$ & $\begin{array}{l}\text { Ratio of PU/ } \\
\text { EC/DNP or } \\
\text { PU/PVP/DNP }\end{array}$ & $\begin{array}{l}\text { PU } \\
(\mathrm{g})\end{array}$ & $\begin{array}{l}\text { EC/PVP } \\
(\mathrm{g})\end{array}$ & $\begin{array}{l}\mathrm{DNP} \\
(\mathrm{g})\end{array}$ & $\begin{array}{l}\text { Solvent } \\
(\mathrm{mL})\end{array}$ \\
\hline F1, F5* & $10 / 1 / 1$ & 12.5 & 1.25 & 1.25 & 100 \\
\hline F2, F6* & $10 / 2 / 1$ & 12.5 & 2.5 & 1.25 & 100 \\
\hline F3, F7* & $10 / 4 / 1$ & 12.5 & 5.0 & 1.25 & 100 \\
\hline F4, F8* & $10 / 8 / 1$ & 12.5 & 10.0 & 1.25 & 100 \\
\hline
\end{tabular}

${ }^{*}$ Contains PVP instead of EC, PVP: Polyvinylpyrrolidone, PU: Polyurethane, EC: Ethyl cellulose, DNP: Donepezil hydrochloride 


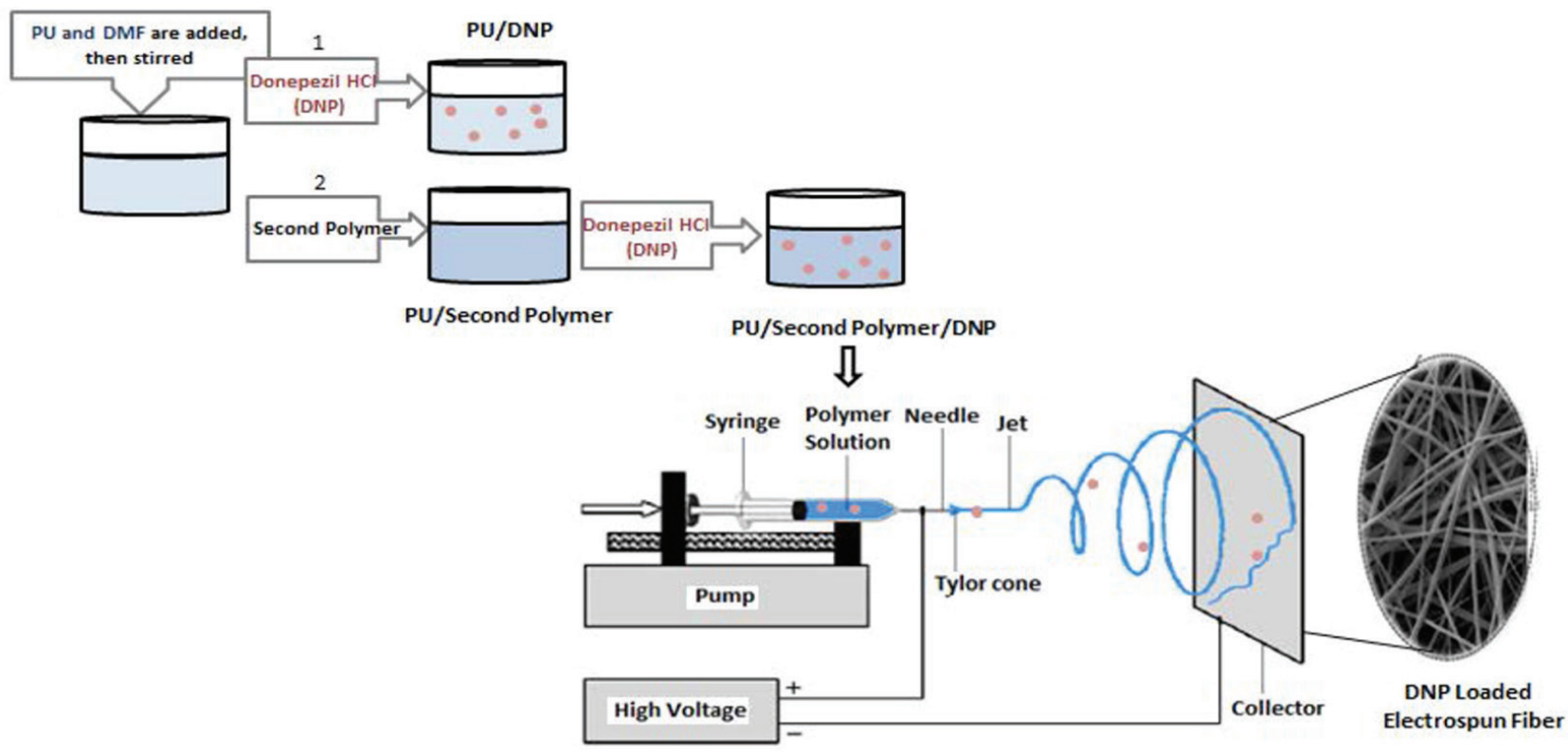

Figure 1. Schematic illustration of the setup of electrospinning and process of preparing polymer solution

PU: Polyurethane, DNP: Donepezil hydrochloride

with a metallic needle of outer diameter $0.8 \times 38 \mathrm{~mm}$. The syringe was mounted on a syringe pump (New Era Pump Systems, USA) and aluminum collector. A positive electrode of high voltage power supply (Gamma High Voltage Inc., USA) was attached to the syringe needle. The polymer solution was fixed at a rate of $1 \mathrm{~mL} / \mathrm{h}$. A high electric voltage was set to $15 \mathrm{kV}$ and the distance between the needle tip and the aluminum collector was $15 \mathrm{~cm}$. All solution preparations and electrospinning were performed at ambient temperature.

\section{Morphology of electrospun nanofibers}

The surface morphology of PU/EC and PU/PVP electrospun nanofibers was examined by a scanning electron microscope (SEM) (Philips-XL30 SFEG, Japan) after each of the samples was coated with a thin layer of gold/palladium alloy to render it electrically conductive. The SEM data were recorded at an accelerating voltage of $20 \mathrm{kV}$ and average fiber diameter (AFD) was estimated via ImageJ by randomly measuring the diameters of 20 different nanofibers in the images for each sample.

\section{Compatibility of components on electrospun nanofibers}

The compatibility of components used in the formulations of nanofibers is crucial for the fabrication of stable nanofibers. For this reason, fourier transform infrared spectroscopy (FTIR) spectroscopic assessments of the nanofibers developed were carried out via attenuated total reflectance-FTIR (ATR) (PerkinElmer, USA).

In vitro drug release from electrospun nanofibers

In vitro drug release studies were carried out in accordance with method defined in the monograph as the "paddle over disk method" of United States Pharmacopeia $38 .{ }^{21} 2.5 \mathrm{~cm}$ in diameter of fiber sections were immobilized between a glass holder and a stainless steel sieve. The samples were immersed into 500 $\mathrm{mL}$ of (phosphate buffer, $\mathrm{pH}$ 6.5) to maintain sink conditions for DNP. At specified time points (from 30 min up to $6 \mathrm{~h}$ ), $2 \mathrm{~mL}$ aliquots of the samples were withdrawn periodically from the release medium and equal volumes of medium were immediately replaced to maintain a constant volume. Concentrations of DNP in the samples were analyzed via a ultraviolet (UV)-visible spectrophotometer (Shimadzu, Japan) at a wavelength of 229 $\mathrm{nm}$. The cumulative amount of released DNP per $\mathrm{cm}^{2}$ through the nanofibers was plotted versus time. Each experiment was conducted three times. UV-visible spectrophotometry was validated for selectivity, linearity, accuracy, and precision. It was determined to be linear over the concentration range $2.5-20 \mu \mathrm{g} /$ $\mathrm{mL}$ with a high correlation coefficient $\left(r^{2}>0.999\right)$ and accuracy (recovery >98\%). There were no interfering absorbances with DNP, verifying selectivity of the method.

\section{Determination of drug release kinetics and modeling}

To understand the mechanism and kinetics of DNP release from electrospun nanofibers, the release results were fitted to kinetic models via the free open source software DDSolver ${ }^{\circledR 22}$ as explained following equations 1-5:

Zero-order kinetic model:

$\mathrm{C}=\mathrm{k}_{0} \mathrm{t}+\mathrm{C}_{0}$

First-order kinetic model:

In $C=\ln \mathrm{C}_{0}+\mathrm{k}_{1} \mathrm{t}$

Higuchi square root kinetic model:

$C=k_{2} t^{1 / 2}$,

where $C$ is the drug concentration released at time $t, C_{0}$ is the drug concentration at the beginning, and $\mathrm{k}_{0}, \mathrm{k}_{1}$, and $\mathrm{k}_{2}$ are zero-order, first-order, and Higuchi release rate constants, respectively.

Hixson-Crowell kinetic model:

$W_{0}^{1 / 3}-W^{1 / 3}=k_{H} t$, 
where $\mathrm{W}_{0}$ and $\mathrm{W}_{\text {, }}$ are the initial and remaining amounts of drug in the nanofiber at time $t$, respectively, and $k_{H}$ is the HixsonCrowell release rate constant.

Korsmeyer-Peppas kinetic model:

$$
M_{t} / M_{\infty}=k_{K P} t^{n} \text {, }
$$

where $M_{t}$ is the drug concentration released at time $t, M_{\infty}$ is the equilibrium concentration of drug that must be released at infinite time in the release medium, $M_{t} / M_{\infty}$ is the fraction of drug in the release medium at time $t, k_{K P}$ is the release rate constant, and $\mathrm{n}$ is the diffusional exponent showing the type of release mechanism. If $n$ equals 1 , the release mechanism is zero order; otherwise, if $0.5<n<1$, non-Fickian transport is the case. Moreover, the first $60 \%$ drug release data were fitted in this model. ${ }^{23}$

The coefficient of correlation $\left(r^{2}\right)$ was calculated using linear curves generated by regression analysis of the drug release profile. The model with the highest $r^{2}$ value was selected as the most feasible.

\section{RESULTS AND DISCUSSION}

\section{Production of electrospun nanofibers}

The solution features (e.g., polymer type and concentration) as well as the electrospinning parameters including the flow rate, applied voltage, and tip-to-collector distance are very important to produce bead-free nanofibers. ${ }^{24}$ Therefore, the preliminary nanofiber fabrication studies were performed using only PU solutions at diverse concentrations and the electrospinning process parameters (e.g., flow rates, applied voltages, and tip-to-collector distance) were tested to determine the optimal parameters and polymer concentration as described in our previous study. ${ }^{25}$ The data had indicated that bead-free nanofibers might be produced with $12.5 \%(\mathrm{w} / \mathrm{v})$ concentration of PU solution. ${ }^{25}$ In the present study, DNP and either EC or PVP in different ratios (Table 1) were added to optimized PU solution and then conductivity of the solutions was determined to observe effect on the morphology of electrospun nanofibers. The conductivity of solutions and the AFD diameter of nanofibers are presented in Table 2. Interestingly, there was a correlated increase in conductivity with increasing AFD diameter of the PU/EC/DNP and PU/PVP/DNP nanofibers. However, this case did not show a linear increase between the conductivity of the polymer solutions and the AFD diameter of the nanofibers, as expected.

\section{Morphology of electrospun nanofibers}

To research effects of EC or PVP amounts on the morphology of PU/DNP electrospun nanofibers and to verify the production of bead-free nanofibers with smooth surfaces, the morphological features of PU/EC/DNP and PU/PVP/DNP nanofibers were examined using SEM analysis. Figures $2 a, 2 b, 3 a$ and $3 b$ present the morphological features and the diameter histograms of PU/ EC/DNP and PU/PVP/DNP nanofibers with diverse ratios of EC and PVP. Most of the electrospun fibers (except for PU/ PVP/DNP at a ratio of 10/8/1) had smooth surfaces and uniform structures without any "beads-on-a-string" morphology.
Table 2. The conductivity of the solutions and average fiber diameter of electrospun fibers $(n=3)$

\begin{tabular}{lll} 
Code & Conductivity $(\mu \mathrm{S} . \mathrm{cm}-1)$ & $\begin{array}{l}\text { Average fiber } \\
\text { diameter }(\mathrm{nm})\end{array}$ \\
\hline $\mathrm{F} 1$ & $109.33 \pm 4.15$ & $410 \pm 47$ \\
\hline $\mathrm{F} 2$ & $115.70 \pm 6.65$ & $556 \pm 46$ \\
\hline $\mathrm{F} 3$ & $116.66 \pm 1.65$ & $518 \pm 39$ \\
\hline $\mathrm{F} 4$ & $123.60 \pm 2.20$ & $603 \pm 42$ \\
\hline $\mathrm{F} 5^{*}$ & $134.03 \pm 3.85$ & $340 \pm 56$ \\
\hline $\mathrm{F} 6^{*}$ & $110.20 \pm 2.70$ & $294 \pm 39$ \\
\hline $\mathrm{F}^{*}$ & $109.57 \pm 2.55$ & $279 \pm 57$ \\
\hline $\mathrm{F} 8^{*}$ & $131.40 \pm 1.50$ & $328 \pm 66$ \\
\hline
\end{tabular}

$\mathrm{F} 1, \mathrm{~F} 2, \mathrm{~F} 3$, and $\mathrm{F} 4$ are described for PU/EC/DNP, F5* $\mathrm{F}^{*}$, F7* , and F8* are described for PU/PVP/DNP nanofibers, PVP: Polyvinylpyrrolidone, PU: Polyurethane, EC: Ethyl cellulose, DNP: Donepezil hydrochloride

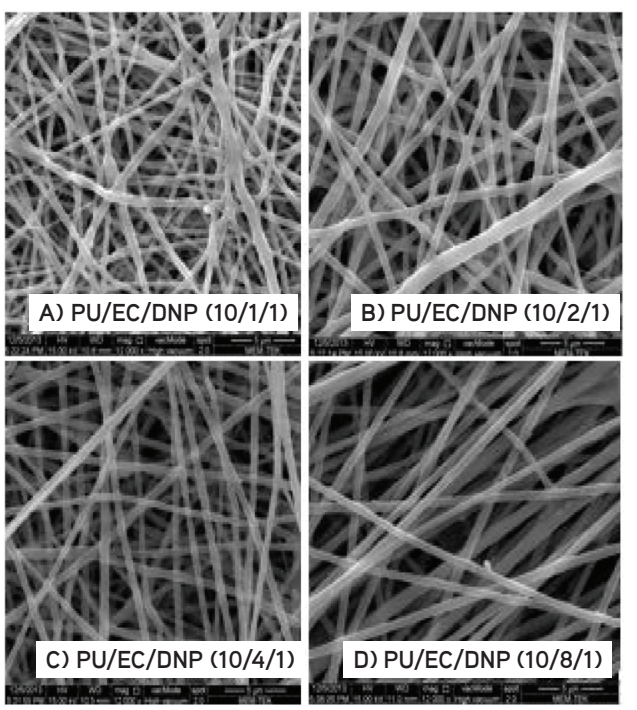

Figure 2a. SEM images of (PU/EC/DNP) (at different ratios) electrospun nanofibers (the scale bars represent $5 \mu \mathrm{m}$ )

SEM: Scanning electron microscope, PU: Polyurethane, EC: Ethyl cellulose, DNP Donepezil hydrochloride
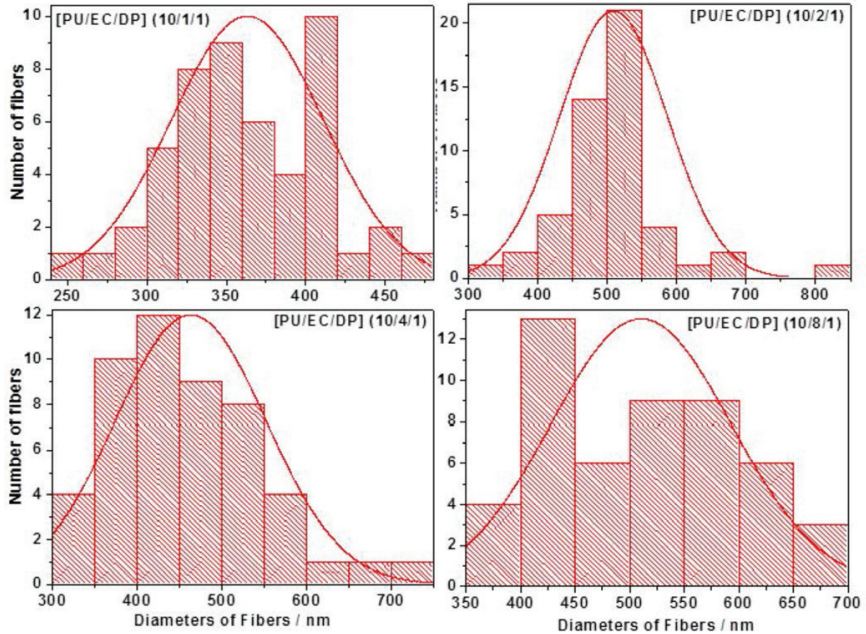

Figure $2 \mathrm{~b}$. Diameter histograms of (PU/EC/DNP) (at different ratios) electrospun nanofibers

PU: Polyurethane, EC: Ethyl cellulose, DNP: Donepezil hydrochloride 
Furthermore, no drug particles were observed on the surface or outside of the nanofibers, revealing good compatibility between the polymers and drug and encapsulation of drug in the nanofibers. SEM images of the PU/EC/DNP nanofibers are given in Figure 2a. The diameter of PU/EC/DNP nanofibers relies upon the existence of $\mathrm{EC}$ in the formulation. PU/DNP (10:1) nanofibers without EC had a mean diameter of $775 \pm 16$ $\mathrm{nm}^{23}$ while the mean diameter of the nanofibers with addition of EC decreased to between $410 \pm 47$ and $603 \pm 42$ (Table 2). In addition, the shape and uniformity of PU/EC/DNP nanofibers were maintained even with increasing EC amount in the nanofibers.

SEM images of PU/PVP/DNP fibers are given in Figure 3a. PU/PVP/DNP nanofibers with diverse ratios of PVP had mean diameters from $279 \pm 57 \mathrm{~nm}$ to $340 \pm 56 \mathrm{~nm}$. The mean diameter of nanofibers decreased with addition of PVP to the formulations, as also seen in PU/EC/DNP nanofibers. However, some clumps were observed in PU/PVP/DNP nanofibers at a ratio of 10/8/1, because of low PVP solubility in electrospinning solution (Figure 3a), as reported previously. ${ }^{17}$ In conclusion, these data confirmed that PU/PVP/DNP and PU/EC/DNP nanofibers with smooth surfaces and bead-free were produced for nearly all of the ratios.

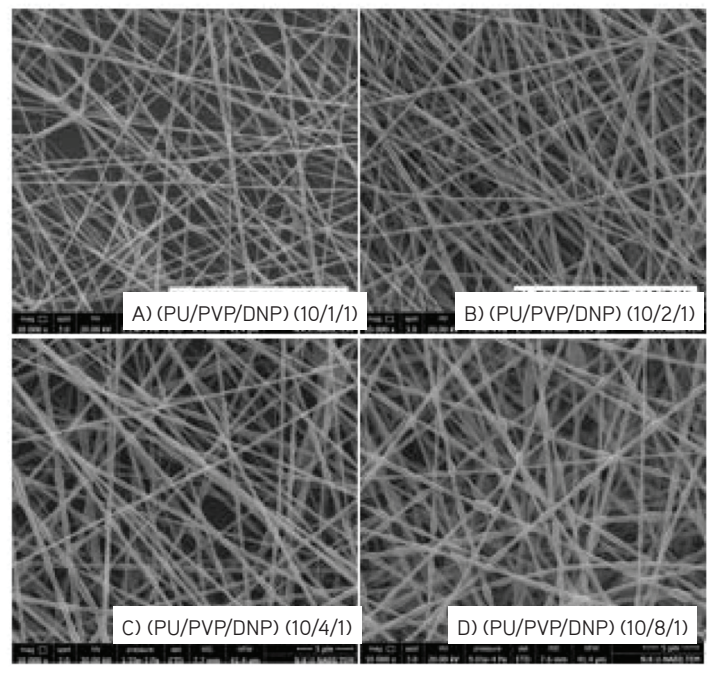

Figure 3a. SEM images of (PU/PVP/DNP) (at different ratios) electrospun nanofibers (the scale bars represent $5 \mu \mathrm{m}$ )

PU: Polyurethane, DNP: Donepezil hydrochloride, PVP: Polyvingl pyrrolidone

\section{Compatibility of components in electrospun nanofibers}

The ATR-FTIR spectra of PU/EC/DNP and PU/PVP/DNP (10/2/1, $10 / 4 / 1,10 / 8 / 1$ ) are seen in Figures 4 and 5 in the wave number range of $4000-800 \mathrm{~cm}^{-1}$; the spectra of $10 / 1 / 1$ were not given because there were no differences between 10/1/1 and 10/2/1. The spectra of drug loaded PU/EC and PU/PVP nanofibers have similar characteristic FTIR bands, but the spectra of fibers also show some small difference. Characteristic absorption bands of PU were described in detail in our previous study, ${ }^{25}$ such as: $1727 \mathrm{~cm}^{-1}$ band, because of carbonyl groups in urethane bonds $(\mathrm{C}=0) ; 1550 \mathrm{~cm}^{-1}$ band, assigned to secondary amide (RCONHR');
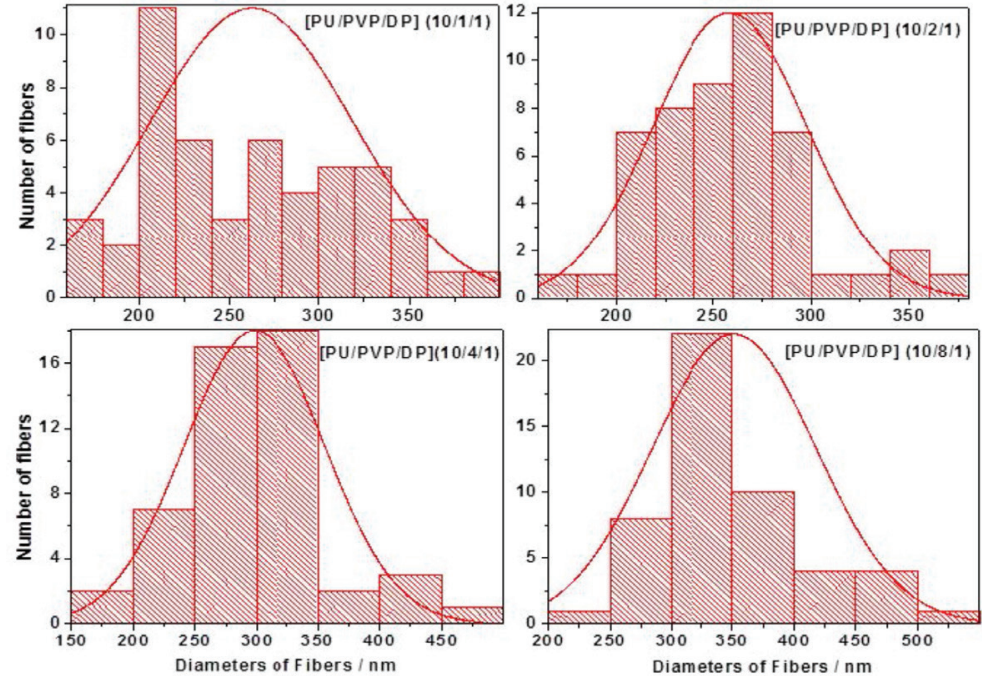

Figure 3b. Diameter histograms of (PU/PVP/DNP) (at different ratios) electrospun nanofibers

PU: Polyurethane, DNP: Donepezil hydrochloride, PVP: Polyvingl pyrrolidone

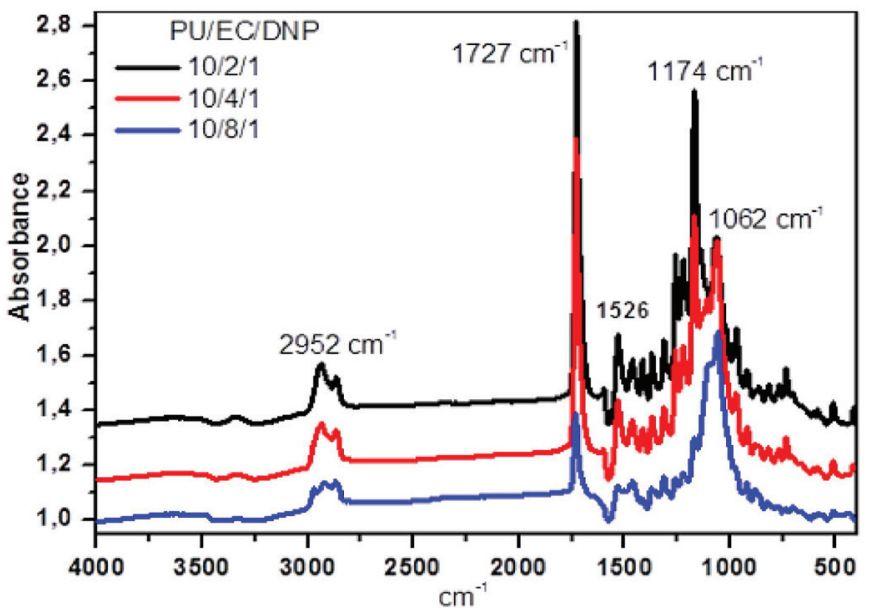

Figure 4. ATR-FTIR spectra of drug loaded electrospun nanofiber of PU/ $\mathrm{EC}$ in various ratios

ATR: Attenuated total reflection, FTIR: Fourier-transform infrared, PU: Polyurethane, EC: Ethyl cellulose

$1630 \mathrm{~cm}^{-1}$ band, assigned to carbonyl groups in urea bonds; 1170 $\mathrm{cm}^{-1}$ band because of $\mathrm{C}-\mathrm{O}$ stretch and $\mathrm{C}-\mathrm{N}$ stretch; $3350 \mathrm{~cm}^{-1}$ and $2944 \mathrm{~cm}^{-1}$ bands from $\mathrm{N}-\mathrm{H}$ and $\mathrm{C}-\mathrm{H}$ groups.

The decrease in characteristic absorption bands of $\mathrm{PU}$ at the $1727 \mathrm{~cm}^{-1}$ band from 10/2/1 to 10/8/1 (PU/EC/DNP) and also amendments at $1062 \mathrm{~cm}^{-1}$ and $2952 \mathrm{~cm}^{-1}$ clarify that EC is incorporated into the PU matrix in Figure 4. Because of the lower rate of the drug according to PU/EC and PU/PVP mixtures, characteristic absorption bands of the drug molecule may not be observed. Hence, the interactions could not be determined between the drug and polymers.

With addition of PVP to PU, new broad peaks located at 3434 $\mathrm{cm}^{-1}$ and $1658 \mathrm{~cm}^{-1}$ are observed in Figure 5. The new band at $3434 \mathrm{~cm}^{-1}$ is because of stretching vibration of the hydroxyl group and at $1658 \mathrm{~cm}^{-1}$ is because of stretching vibration of 
the $\mathrm{C}=0$. The increase at $2949 \mathrm{~cm}^{-1}$ is assigned to the $\mathrm{C}-\mathrm{H}$ asymmetric stretching vibration from PVP.

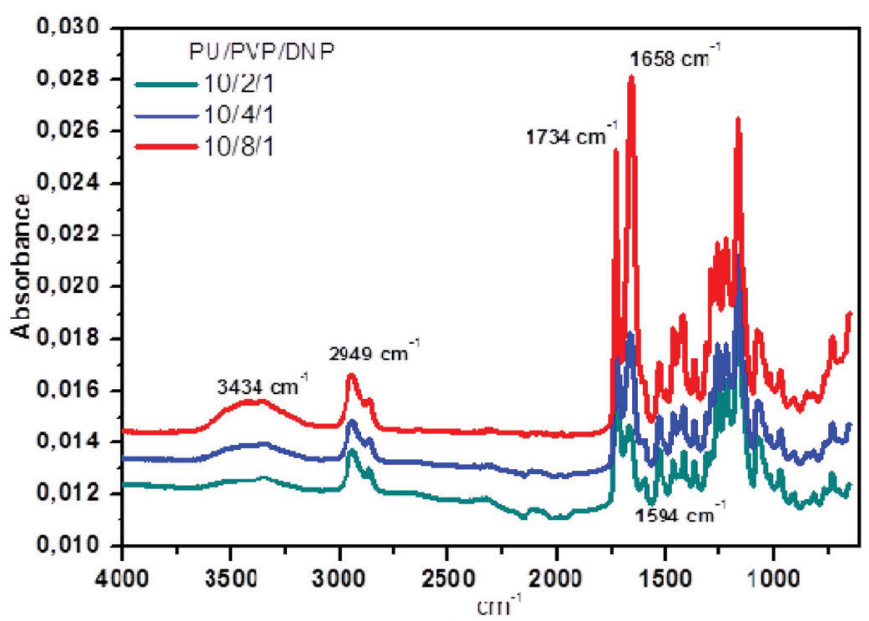

Figure 5. ATR-FTIR spectra of drug loaded electrospun fiber of PU/PVP in various ratios

ATR: Attenuated total reflection, FTIR: Fourier-transform infrared, PVP: Polyvinylpyrrolidone, PU: Polyurethane

\section{In vitro drug release studies}

PU/EC/DNP and PU/PVP/DNP nanofibers were used to research effect of EC and PVP amounts on drug release. The drug release profiles from PU/EC nanofibers are presented in Figure 6.

All of the nanofibers exhibited biphasic drug release with moderately fast release in $30 \mathrm{~min}$. The highest amount of drug release was observed for PU/PVP/DNP (10/8/1) nanofibers with the highest ratio of PVP (data not given). Conversely, an increase in the EC amount in the formulation caused a reduction in drug release (Figure 6). While approximately $350 \mu \mathrm{g} / \mathrm{cm}^{2}$ DNP from PU/PVP/DNP (10/8/1) nanofibers was released in $1 \mathrm{~h}$ (data not given), the concentration of released DNP from PU/EC/DNP (10/8/1) nanofibers was around $100 \mu \mathrm{g} / \mathrm{cm}^{2}$ (approximately 20\%) at the end of $1 \mathrm{~h}$. This might be explained by the hydrophilic property of PVP, which could gradually accelerate the release of drug from PU nanofibers. In the case of $E C$, the slow drug release could be attributed to its hydrophobic character. Moreover, some clumps on the nanofibers with PVP (Figure 3a) could have resulted in high immediate drug release. Interestingly, for both nanofiber groups, no linear correlation between amount of drug released and ratios of PVP or EC was found. The data indicated that EC might induce retention of water-soluble drugs in the nanofibers, which resulted in inhibiting drug release and presenting sustained drug release, as reported previously. ${ }^{26}$ Conversely, PVP might expedite the release of a water-soluble drug. Furthermore, it is well known that water-soluble drugs exhibit a fast release profile; this is a crucial point for controlled release of these drugs. ${ }^{27}$ In the light of these data, sustained release of water-soluble drugs from $\mathrm{PU} / \mathrm{EC}$ nanofibers might be possible, with increased ratio of EC (Figure 6).

\section{Determination of drug release kinetics and modeling}

The in vitro release results of nanofibers were analyzed using kinetic models aforementioned in the method section, in order to explain the release mechanism of DNP from PU/EC electrospun nanofibers. The drug release mechanism and kinetics were determined depending on $r^{2}$ values, which signify goodness of fit. Table 3 shows the $r^{2}$ values calculated via linear curves of PU/EC/DNP electrospun fibers. In addition, $r^{2}$ values were not estimated for kinetic models as drug release from PU/PVP/DNP electrospun fibers was immediate. The regressed results for PU/ EC/DNP nanofiber (10/8/1) showed the highest $r^{2}$ value (0.999) (Table 3) for the Korsmeyer-Peppas model. This revealed that release of DNP from this nanofiber was controlled by a Fickian diffusion mechanism with a value of release exponent $(n)$ of 0.31 (<0.5). DNP was released by molecular diffusion depending on drug gradient. A similar release kinetic has also been reported by Yu et al. ${ }^{28}$ for ketoprofen-loaded PVP/EC nanofibers. However, the other nanofibers with EC did not fit the Korsmeyer-Peppas model (Table 3). In this case, an increase in EC ratio of the nanofibers could influence the release kinetics and mechanisms of a water-soluble drug, causing sustained-drug release. This improvement in PU/EC/DNP electrospun fiber (10/8/1) might be attributed to the hydrophobic nature of EC.

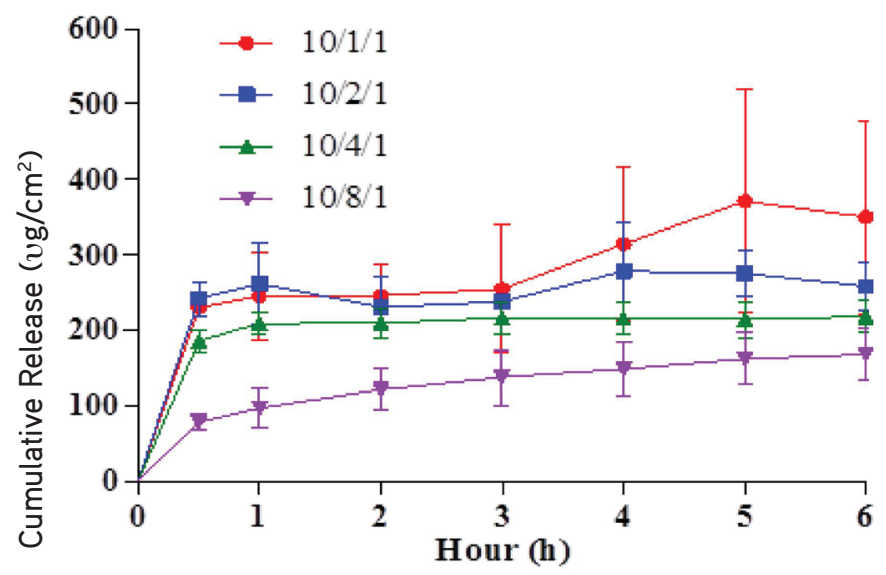

Figure 6. In vitro release profiles of DNP from PU/EC nanofibers DNP: Donepezil hydrochloride, PU: Polyurethane, EC: Ethyl cellulose

Table 3. Coefficient of correlation $\left(r^{2}\right)$ values for DNP loaded PU/ EC nanofibers

\begin{tabular}{lllll} 
& \multicolumn{4}{l}{ Ratio of PU/EC/DNP } \\
\hline Kinetic models & $10 / 1 / 1$ & $10 / 2 / 1$ & $10 / 4 / 1$ & $10 / 8 / 1$ \\
\hline Zero order & 0.905 & 0.240 & 0.542 & 0.949 \\
\hline First order & 0.922 & 0.241 & 0.530 & 0.896 \\
\hline Hixson-Crowell & 0.917 & 0.241 & 0.534 & 0.915 \\
\hline Higuchi square root & 0.863 & 0.358 & 0.658 & 0.994 \\
\hline Korsmeyer-Peppas & 0.797 & 0.493 & 0.767 & 0.999 \\
\hline (n) & $(0.14)$ & $(0.04)$ & $(0.05)$ & $(0.31)$ \\
\hline
\end{tabular}

PU: Polyurethane, EC: Ethyl cellulose, DNP: Donepezil hydrochloride 


\section{CONCLUSION}

Electrospun nanofibers composed of different blends of either PU/EC or PU/PVP have been utilized by electrospinning. DNP was loaded into these nanofibers as a water-soluble model drug. All electrospun nanofibers fabricated had smooth surfaces and uniform structures without any beads-on-astring morphology. The PU/EC electrospun nanofibers showed a Korsmeyer-Peppas drug release kinetic mechanism in which the release rate was controlled by diffusion of drug when the EC ratios were increased in the nanofiber composition. The data also suggest that types and ratios of polymer blends need to be adjusted so as to optimize the drug release rate. Overall, this ability of PU/EC (10/8) electrospun nanofibers suggested their potential use as a drug carrier from which water-soluble drug release may be sustained.

\section{ACKNOWLEDGEMENTS}

This work was supported by the Scientific Research Projects Coordination Unit of İstanbul Technical University (project number: 37960).

Conflicts of interest: No conflict of interest was declared by the authors. The authors alone are responsible for the content and writing of the paper.

\section{REFERENCES}

1. Bhardwaj N, Kundu SC. Electrospinning: a fascinating fiber fabrication technique. Biotechnol Adv. 2010;28:325-347.

2. Luong-Van E, Grøndahl L, Chua KN, Leong KW, Nurcombe V, Cool SM. Controlled release of heparin from poly(epsilon-caprolactone) electrospun fibers. Biomaterials. 2006;27:2042-2050.

3. Vrbata $P$, Berka $P$, Stránská $D$, Doležal $P$, Lázníček M. Electrospinning of diosmin from aqueous solutions for improved dissolution and oral absorption. Int J Pharm. 2014;473:407-413.

4. Hu X, Liu S, Zhou G, Huang Y, Xie Z, Jing X. Electrospinning of polymeric nanofibers for drug delivery applications. J Control Release. 2014;185:12-21.

5. Akduman C., Akçakoca Kumbasar EP. Electrospun Polyurethane Nanofibers. In: Yllmaz F (ed). Aspects of Polyurethanes. London; IntechOpen; 2017: Chapter 2.

6. Raschip IE, Vasile C, Macocinschi D. Compatibility and biocompatibility study of new HPC/PU blends. Polym Int. 2009;58:4-16.

7. Uslu I, Aytimur A, Serincay $H$. Preparation of PVA/PAA/PEG/PVP nanofibers with HPMC and aloe vera. Curr Nanosci. 2013;9:489-493.

8. Wilmington DE. Polymer blend matrix for oral sustained drug delivery. Pharmaceutical Technology Report 016. Hercules Incorporated, Aqualon Division. 2002.

9. Callahan JC, Cleary GW, Elefant M, Kaplan G, Kensler T, Nash RA. Equilibrium moisture content of pharmaceutical excipients. Drug Dev Ind Pharm. 2008;8:355-369.

10. Huang LY, Branford-White C, Shen XX, Yu DG, Zhu LM. Timeengineeringed biphasic drug release by electrospun nanofiber meshes. Int J Pharm. 2012;436:88-96.

11. Emeje MO, Kunle OO, Ofoefule SI. Compaction characteristics of ethylcellulose in the presence of some channeling agents: Technical note. AAPS PharmSciTech. 2006;7:E18-E21.
12. Yang GZ, Li HP, Yang JH, Wan J, Yu DG. Influence of working temperature on the formation of electrospun polymer. Nanoscale Res Lett. 2017;12:55-65.

13. Illangakoon UE, Gill H, Shearman GC, Parhizkar M, Mahalingam S, Chatterton NP, Williams GR. Fast dissolving paracetamol/caffeine nanofibers prepared by electrospinning. Int J Pharm. 2014;477:369-379.

14. Li CC, Wang ZH, Yu DG, Williams GR. Tunable biphasic drug release from ethyl cellulose nanofibers fabricated using a modified coaxial electrospinning process. Nanoscale Res Lett. 2014;9:258-268.

15. Samprasit W, Akkaramongkolporn P, Ngawhirunpat T, Rojanarata T, Kaomongkolgit R, Opanasopit P. Fast releasing oral electrospun PVP/CD nanofiber mats of taste-masked meloxicam. Int J Pharm. 2015;487:213-222.

16. $\mathrm{Xu} \mathrm{J}$, Jiao $\mathrm{Y}$, Shao $X$, Zhou C. Controlled dual release of hydrophobic and hydrophilic drugs from electrospun poly (l-lactic acid) fiber mats loaded with chitosan microspheres. Mater Lett. 2011;65:2800-2803.

17. Yu DG, Shen XX, Branford-White C, White K, Zhu LM, Bligh SW. Oral fast-dissolving drug delivery membranes prepared from electrospun polyvinylpyrrolidone ultrafine fibers. Nanotechnology. 2009;20:055104.

18. Yu DG, Branford-White C, Williams GR, Bligh SA, White K, Zhu LM, Chatterton NP. Self-assembled liposomes from amphiphilic electrospun nanofibers. Soft Matter. 2011;7:8239-8247.

19. Park JY, Kim JI, Lee IH. Fabrication and characterization of antimicrobial ethyl cellulose nanofibers using electrospinning techniques. J Nanosci Nanotechnol. 2015;15:5672-5675.

20. Yu DG, Wang X, Li XY, Chian W, Li Y, Liao YZ. Electrospun biphasic drug release polyvinylpyrrolidone/ethyl cellulose core/sheath nanofibers. Acta Biomater. 2013;9:5665-5672.

21. United State Pharmacopeia (USP) 38-NF33 Chapter Topical and transdermal drug products- Product Performance Tests for TDS. $750: 764$.

22. Zhang Y, Huo M, Zhou J, Zou A, Li W, Yao C, Xie S. DDSolver: An addin program for modelling and comparison of drug dissolution profile. APPS J. 2010;12:263-272.

23. Dash S, Murthy PN, Nath L, Chowdhury P. Kinetic modeling on drug release from controlled drug delivery systems. Acta Pol Pharm-Drug Res. 2010;67:217-223.

24. Zamani M, Prabhakaran MP, Ramakrishna S. Advances in drug delivery via electrospun and electrosprayed nanomaterials. Int J Nanomed. 2013;8:2997-2917.

25. Gencturk A, Kahraman E, Güngör S, Özhan G, Özsoy Y, Sarac AS. Polyurethane/hydroxypropyl cellulose electrospun nanofiber mats as potential transdermal drug delivery system: characterization studies and in vitro assays. Artif Cells Nanomed Biotechnol. 2017;45:655-664.

26. Rowe RC, Sheskey PC, Quinn ME. Handbook of Pharmaceutical Excipients. London: Pharmaceutical Press; 2009.

27. Enayatifard R, Saeedi M, Akbari J, Tabatabaee YH. Effect of hydroxypropyl methylcellulose and ethyl cellulose content on release profile and kinetics of diltiazem $\mathrm{HCl}$ from matrices. Trop J Pharm Res. 2009;8:425-432.

28. Yu DG, Wang X, Li XY, Chian W, Li Y, Liao YZ. Electrospun biphasic drug release polyvinylpyrrolidone/ethyl cellulose core/sheath nanofibers. Acta Biomater. 2013;9:5665-5672. 